\title{
Perilaku Spasio Temporal Tikus Sawah (Rattus argentiventer) Betina
}

\section{Spatio Temporal Behavior of Female Ricefield Rat (Rattus argentiventer)}

\author{
Susilo Hadi $^{1}$, Jusup Subagja ${ }^{1}$, Sudarmaji ${ }^{2}$ \\ 1 Fakultas Biologi, Universitas Gadjah Mada Jogjakarta \\ E-mail: susilo-hadi@lycos.com *Penulis untuk korespondensi \\ 2 Balai Penelitian Padi (BALITPA) Sukamandi Subang Jawa Barat
}

\begin{abstract}
This research aimed to study spatio temporal behavior of the female ricefield rat, Rattus argentiventer, including home range, range spans, habitat use and daily activity. Twelve rats were released in two locations of a ricefield area from June $11^{\text {th }}$ until July $24^{\text {th }}, 2001$. The movement of each rat was monitored using radio-tracking three times a day. The result was used for calculating home range size, range spans, habitat used and daily activities of female field-rats, using the computer program Ranges $V$. The results showed that the average female ricefield-rat's home ranges and range spans were $0.84 \pm 0.16 \mathrm{Ha}$ and $184.54 \pm 22.7 \mathrm{~m}$ respectively. During daylight, the rats spent $82 \%, 16 \%$ and $2 \%$ of their activity living in dikes, in villages and in ricefield respectively. On the contrary, during the night $95 \%, 3 \%$ and $2 \%$ of the rats were active in the ricefield, villages and dikes respectively.
\end{abstract}

Key words: spatial-temporal behavior, Rattus argentiventer

Diterima: 10 Oktober 2005, disetujui: 20 Januari 2006

\section{Pendahuluan}

Tikus sawah (Rattus argentiventer) merupakan salah satu anggota Ordo Rodentia penyebab kerusakan tanaman padi di daerah Asia Tenggara. Di Indonesia, kerusakan padi sebelum panen yang disebabkan oleh tikus diperkirakan mencapai 17\% (Geddes, 1992; Singleton \& Petch, 1994). Kerusakan tersebut andaikan dapat dikurangi setengahnya saja, diperkirakan cukup untuk menghidupi 17 juta penduduk dalam setahun (Singleton, 2001).

Berbagai upaya pemberantasan tikus telah dilakukan antara lain dengan cara pengasapan, pemagaran, peracunan, perusakan liang, pola tanam serempak dan pelepasan predator. Dewasa ini strategi pengendalian tikus sudah mulai mengurangi penggunaan racun rodentisida. Kondisi ini dipicu oleh tiga faktor, pertama, tingginya biaya penggunaan rodentisida yang selalu dibutuhkan tiap musim tanam. Kedua, dampak lingkungan yang diterima dari penggunaan rodentisida yang dapat meracuni spesies bukan sasaran dan ketiga, kebutuhan pasar mulai menuntut produk pertanian yang ramah lingkungan.

Salah satu usaha managemen pengendalian tikus hama yang efektif dan ramah lingkungan menuntut pengetahuan dasar dari biologi tikus di alam. Sedikit diketahui perilaku penggunaan ruang dan waktu oleh tikus sawah di areal persawahan Indonesia dengan berbagai variasi ekosistemnya. Studi pertama dengan metode plot traping dilakukan di Malaysia menunjukkan bahwa luas daerah jelajah tikus sawah adalah berdiameter $80 \mathrm{~m}$ atau sekitar 0,5 Ha (Brown et al., 2001). Selanjutnya Murakami et al., (1992) dalam suatu penelitiannya mengatakan bahwa daerah jelajah tikus sawah adalah seluas antara 0,25 Ha hingga 1,0 Ha. Dilaporkan juga bahwa, jika tikus merasa tidak aman lagi di suatu area atau tidak tersedianya pakan yang memadai, maka mereka akan pergi mencari area baru untuk melakukan aktivitasnya sejauh 1-2 km. Menurut Rochman dan Sukarna (1991), batas 
ruang gerak tikus sangat dipengaruhi oleh ketersediaan makanan. Jika makanan cukup tersedia dan ada tempat untuk berlindung, maka jarak tempuh tikus hanya sekitar $200 \mathrm{~m}$, namun jika makanan tidak cukup tersedia, maka tikus dapat bergerak sejauh lebih dari $700 \mathrm{~m}$.

Tujuan penelitian ini adalah untuk mengetahui perilaku spasio-temporal tikus sawah betina (Rattus argentiventer), meliputi daerah jelajah, jarak tempuh dan tipe habitat yang digunakan pada siang dan malam hari. Berbeda dengan beberapa penelitian sebelumnya, penelitian perilaku ini menggunakan pemantauan radio (radio tracking) yang diharapkan menghasilkan akurasi data yang lebih tinggi, dengan fokus penelitian pada tikus betina.

\section{Metode Penelitian}

Lokasi penelitian berupa ekosistem sawah irigasi teknis yang terletak di daerah dataran rendah 15,96 m dpl. Kondisi iklim di daerah ini bersifat tropis, suhu tahunan rata-rata $28^{\circ} \mathrm{C}$ dan hujan tahunan rata-rata sebesar $1,45 \mathrm{~mm}$. Lokasi penelitian terbagi menjadi dua yaitu di desa Sengon (lokasi 1) dan desa Pangkalan (lokasi 2), Kecamatan Ciasem, Kabupaten Subang, Jawa Barat $\quad\left(6^{0} 20^{\prime} \mathrm{S}, \quad 107^{0} 39^{\prime} \mathrm{E}\right) . \quad$ Pelaksanaan penelitian dilakukan pada musim kemarau, tanggal 11 Juni sampai dengan 24 Juli 2001. Pada saat itu padi berada pada stadium anakan sampai dengan stadium masak. Sebagian besar lahan pertanian ditanami padi varietas Ciherang.

Sebanyak 12 ekor tikus betina diperangkap di dua lokasi penelitian dengan Linear Trap Barrier System (Singleton \& Petch, 1994). Semua tikus diberi kalung radio pemancar (Sirtrack ${ }^{T M}$ New Zealand) dengan frekuensi identitas antara $150.02 \mathrm{MHz}-150.98$ MHz. Sebelum pemasangan kalung pemancar, tikus diberikan larutan sedatif, xylazil, yang diinjeksikan secara intraperitonial untuk memberikan efek bius ringan. Selanjutnya setelah pemasangan radio pemancar selesai, tikus diberikan suntikan antisedan atepamezole hydrochloride secara intraperitonial atau subcutaneous untuk menyadarkan kembali. Semua tikus penelitian dilepas kembali di tempat mereka diperangkap pada malam harinya.

Pemantauan pergerakan tiap-tiap tikus (radio-tracking) dilakukan dalam periode waktu: sekali pada siang (08.00-11.00) dan dua kali pada malam hari (18.00-24.00). Proses pelacakan tikus dilakukan dengan cara mendeteksi frekuensi tiap-tiap pemancar yang dipasang pada tikus dengan radio penerima dan antena pengarah YAGI 3 element (Sirtack $^{T M}$ New Zealand). Data lapangan yang dikumpulkan adalah lokasi koordinat, tipe habitat (sawah, pematang dan pemukiman) dan waktu pemantauan.

Data lapangan kemudian diolah dengan perangkat lunak RANGES $V$ (Kenward \& Hodder, 1996) untuk menentukan luas daerah jelajah, jarak tempuh, tipe habitat yang digunakan dan aktivitas harian. Area penelitian dan kedudukan tikus dipetakan dalam bentuk Grid System dengan bantuan Microsoft Exel 2000.

\section{Hasil dan Pembahasan}

Sebanyak 12 ekor tikus sawah betina yang telah dilepaskan, namun satu ekor mengalami gagal pantau karena pemancarnya lepas. Dengan demikian sampai akhir pemantauan tinggal 11 ekor tikus. Total 815 titik pantau telah digunakan untuk analisis, dan rata-rata titik pantau per individu adalah 74, 99. Hasil analisis incremental area (Kenward \& Hodder, 1996) menghasilkan minimum 39 titik pantau sebagai syarat untuk mendeterminasi $80 \%$ dari $95 \%$ convek poligon minimum berdasarkan sofwere Ranges V.

Hasil perhitungan daerah jelajah menunjukkan bahwa luas rata-rata daerah jelajah tikus sebesar $0,84 \pm 0,16 \mathrm{Ha}$, rata-rata jarak tempuh sejauh $184,54 \pm 22,7 \mathrm{~m}$ tidak jauh berbeda dengan laporan Rochman dan Sukarna (1991) dan Murakami et al., (1992). Artinya kondisi pakan termasuk dalam kisaran suplai yang melimpah sehingga tidak banyak tikus yang melakukan migrasi untuk memperoleh suplai pakan dengan jarak yang relatif jauh.

Perilaku suatu hewan merupakan cara suatu hewan berinteraksi dengan lingkungan. 
Perilaku tersebut hasil dari seleksi alam dan tanggapan terhadap kondisi lingkungannya. Suatu populasi hewan terdistribusi dalam dimensi ruang, misalkan penggunaan daerah jelajah yang berlainan, dan dimensi waktu, misalkan sifat aktivitasnya yang dipengaruhi irama gelap terang harian, siklus bulan dan lain sebagainya. Daerah jelajah dapat diartikan sebagai daerah dimana hewan biasanya hidup. Suatu daerah jelajah dapat dipertahankan seluruhnya atau sebagian (disebut daerah teritori), dan dapat tumpang tindih dengan daerah jelajah individu lainnya (Smith, 1990). Sedangkan jarak tempuh adalah jarak antara dua titik terjauh yang ditempuh suatu hewan dalam suatu daerah jelajah (Brown et al., 2001).
Secara umum pola daerah jelajah tiap tiap tikus dapat dilihat pada Gambar 1 dan 2. Pola peta daerah jelajah itu memperlihatkan beberapa kesamaan. Pertama, letak sarang berada di suatu tempat di bagian tepi daerah jelajah, dekat dengan sumber air atau pematang. Kedua, daerah jelajah berada di area dalam suatu sudut tertentu dari posisi sarang. Ketiga, daerah jelajah tikus cenderung terbatas oleh penghalang-penghalang alam seperti jalan besar, tanggul dan sungai. Walaupun demikian penghalang tersebut pada dasarnya bukan faktor yang berarti karena mobilitas tikus yang sangat tinggi. Besar kemungkinan karena ketersediaan pakan yang cukup, pergerakan melintasi penghalang tersebut relatif tidak dilakukan.

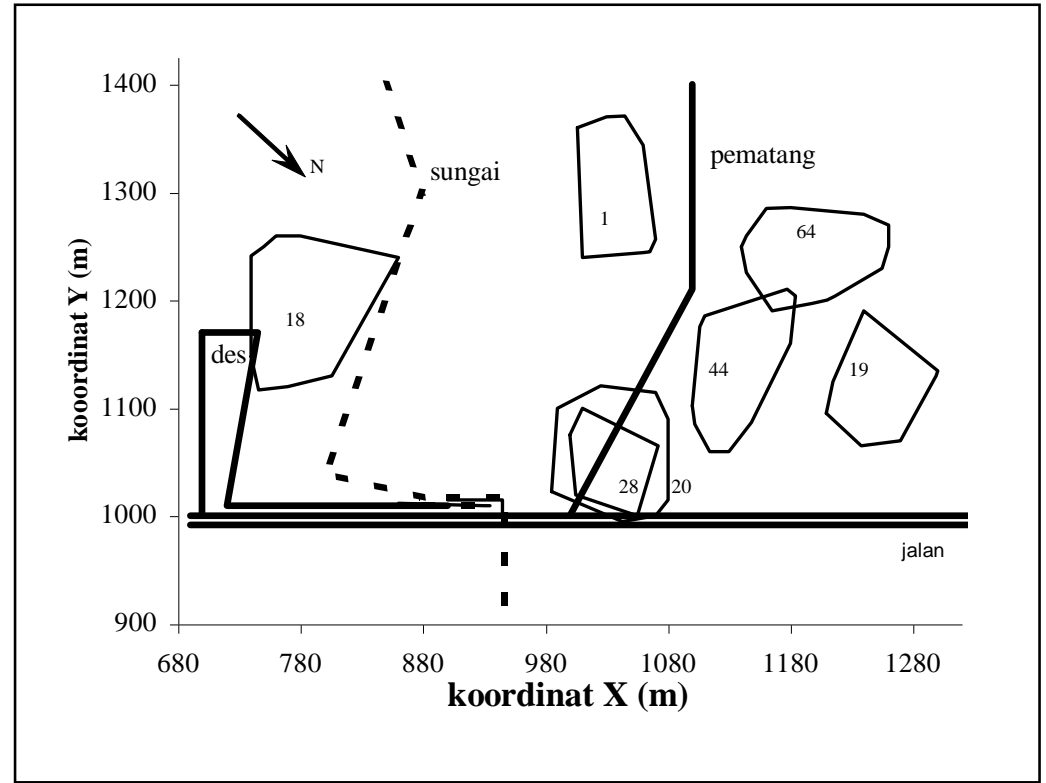

Gambar 1. Daerah jelajah 7 ekor tikus sawah betina (Rattus argentiventer) di lokasi I Identitas tikus berdasarkan nomor frekuensi.

Ukuran daerah jelajah pada mamalia kecil dapat bervariasi tergantung factor intrinsik dan ekstrinsik. Faktor intrinsik contohnya adalah aktivitas kawin (McShea, 1989) dan densitas populasi (Erlinge et al., 1990), sedangkan faktor ekstrinsik seperti ketersediaan pakan (Ostfeld, 1986), tingginya vegetasi dan penghindaran dari predator (Jacob \& Hempel, 2002). Pada penelitian ini, pola daerah jelajah tikus yang relatif sama menunjukkan tekanan-tekanan seperti faktor ketersediaan pakan, tingginya vegetasi maupun penghindaran terhadap predator merupakan tekanan yang seragam. Seperti diketahui bahwa dukungan pakan berada dalam keadaan maksimal dan tingginya vegetasi berada pada fase pertumbuhan yang seragam saat penelitian berlangsung. Pada faktor predasi, posisi semua tikus sama-sama sebagai hewan yang dimangsa. Hewan yang dijadikan target pemangsaan harus memiliki suatu trade of antara kemampuan menghindari predator dan kemampuan untuk terus beraktivitas dalam memenuhi kebutuhan hidupnya. Sekalipun 
demikian tikus yang memiliki anak ada keharusan untuk menjaganya yang mungkin menjadi faktor yang lebih besar untuk tidak jauh dari sarang.

Persentase tumpang tindih daerah jelajah sebesar $66 \%$. Sebagai perbandingan pada Mus domesticus betina memiliki daerah jelajah yang tumpang tindih sebesar $13 \%$ pada musim kawin (Chambers et al., 2000). Besarnya persentase tumpang tindih daerah jelajah menunjukkan bahwa tikus memiliki hubungan sosial intraspesies yang tinggi sehingga antar anggotanya dapat menggunakan ruang aktif bersama-sama. Andaikan ada wilayah teritori yang harus dipertahankan, nampaknya tidak menunjukkan suatu daerah yang luas. Bahkan, kemungkinan wilayah teritorinya hanya terbatas pada sarangnya saja. Namun demikian sekalipun kecil, kasus terjadinya kompetisi ruang sangat mungkin terjadi seperti pada tikus nomor 78 yang melakukan migrasi.

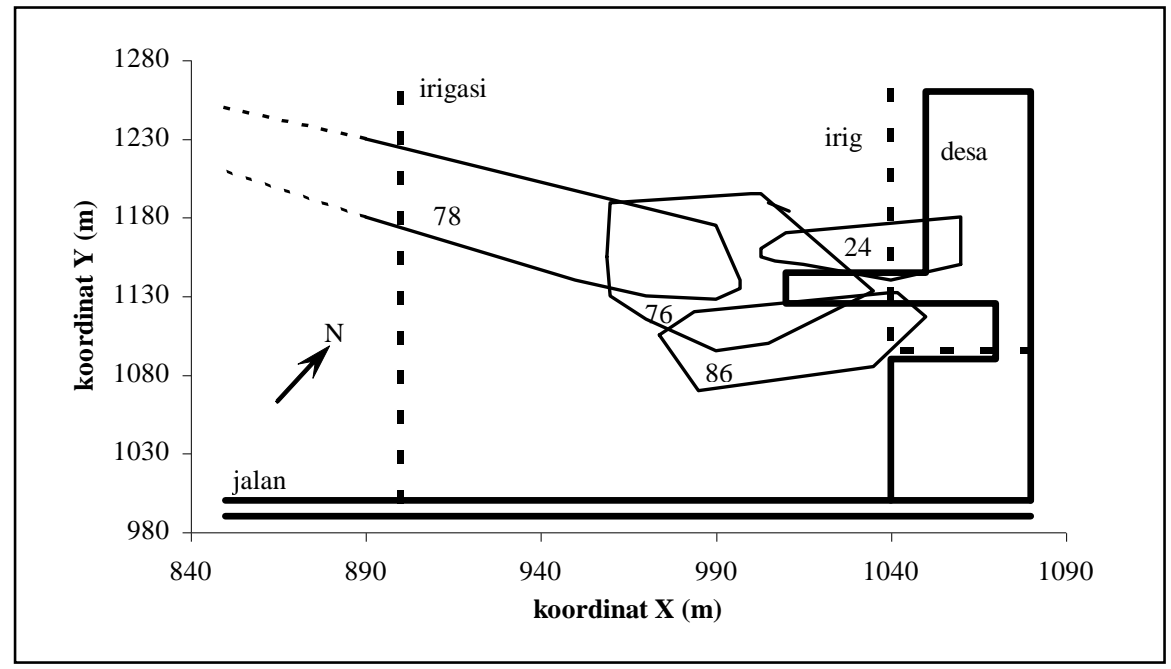

Gambar 2. Daerah jelajah 4 ekor tikus sawah betina (Rattus argentiventer) di lokasi II. Identitas tikus berdasarkan nomor frekuensi.

Berdasarkan tipe habitat yang digunakan dan aktivitas harian, keberadaan tikus-tikus yang dipantau dalam suatu area yang dibedakan menjadi tiga area: tengah sawah dimana tikus diasumsikan aktif mencari sumber pakan, bersosialisasi dan lain-lain; pematang, yang diasumsikan sebagai tempat beristirahat dan di areal pemukiman yang diasumsikan sebagai lokasi mencari suplai pakan tambahan.

Sebagai omnivora, selain mengkonsumsi padi, tikus juga makan umbi-umbian, gulma, serangga dan binatang air (Rahmini \& Sudarmaji, 1998). Apabila makanan berlimpah mereka cenderung memilih makanan yang disukai seperti biji padi. Sedangkan pada kondisi lahan bera, tikus ini sering masuk ke pemukiman dan gudang-gudang padi (Sukarna et al., 1980). Tipe habitat yang digunakan ini di bedakan antara siang dan malam hari.

Hasil penelitian menunjukkan, pada malam hari $95 \%$ tikus berada di tengah sawah, Biota Vol. XI (2), Juni 2006
$3 \%$ di daerah pemukiman dan $2 \%$ berada di pematang. Sebaliknya pada siang hari $82 \%$ berada di pematang, $16 \%$ di areal pemukiman dan hanya $2 \%$ berada di tengah sawah (Gambar 3). Data penggunaan habitat berdasarkan aktivitas harian ini menunjukkan pola umum tikus yang aktivitas hidupnya dilakukan pada malam hari (nocturnal). Pada malam hari tikus aktif menghabiskan waktu di tengah sawah untuk mencari makan, mencari pasangan dan bersosialisasi lainnya. Sedangkan pada siang hari, tikus banyak menghabiskan waktu di dalam sarang untuk beristirahat yaitu di pematang atau ladang pemukiman.

Memang ada kemungkinan di siang hari tikus aktif bergerak. Hal tersebut disebabkan antara lain oleh respons fisiologi terhadap kelembaban di daerah tropis, mencari pasangan untuk kawin, berkompetisi untuk memperebutkan tempat tinggal (sarang), dan karena diserang oleh tikus lain (Brown et al., 2001). Namun demikian pada penelitian ini, 
berdasarkan pantauan lapangan, menunjukkan bahwa keberadaan tikus di siang hari dalam area persawahan atau pemukiman lebih cenderung karena sarangnya berada di daerah itu, bukan karena aktivitas tikus untuk mencari sumber pakan. Sudarmaji (1994) mengatakan bahwa sejalan rimbunnya pertumbuhan padi, ada kemungkinan tikus sawah untuk berpindah sarang akan semakin besar karena mencari lokasi yang lebih terlindung dan tersembunyi.

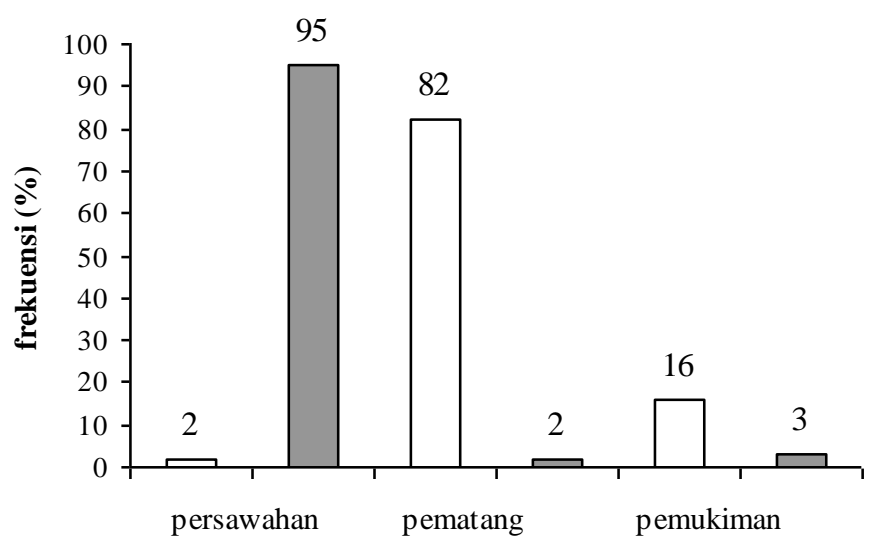

Gambar 3. Penggunaan habitat yang digunakan tikus sawah betina ( $R$. argentiventer) pada siang $\square$ ) dan malam hari $(\square)$.

\section{Kesimpulan}

Kesimpulan dari penelitian ini adalah bahwa luas daerah jelajah tikus sawah betina rata-rata adalah $0,84 \pm 0,16 \mathrm{Ha}$ dan rata-rata jarak tempuhnya sejauh $184,54 \pm 22,7 \mathrm{~m}$. Pada siang hari tikus betina lebih banyak berada di daerah pematang sawah $82 \%$ areal pemukiman $16 \%$ dan tengah persawahan $2 \%$, sedangkan pada malam hari berada di tengah sawah $95 \%$, pemukiman $3 \%$ dan pematang $2 \%$.

\section{Ucapan Terima Kasih}

Peneliti mengucapkan terima kasih kepada saudara Yustianus Matullesi, Anik dan Abrar yang banyak membantu dalam penelitian ini.

\section{Daftar Pustaka}

Brown, P., Singleton, G.R. and Sudarmaji. 2001. Habitat use and movements of the ricefield rat, Rattus argentiventer, in west Java, Indonesia, Mammalia, 65: 151 - 166.
Erlinge, S., Hoogenboom, I., Agrell, J., Nelson, J. and Sandell, M. 1990. Density-related home range size and overlap in adult field voles (Nicrotus agrestis) in southern Sweden. Journal of Mammalogy 71: 597-603.

Chambers, L.K., Singleton, G.R. and Krebs, C.J. 2000. Movements and Social Organization of Wild House Mice (Mus domesticus) in the Wheatlands of Northwestern Victoria, Australia, J. Mammalia 81: 59 - 69

Geddes, A.W.M. 1992. The relative importance of preharvest crop pests in Indonesia. Natural resource Institute Bulletin 47: 70

Jacob, J. and Hempel, N. 2002. Effects of farming practices on spatial behavior of common voles. Journal of Ethology 10: 173-178

Kenward, R.E. and Hodder, K.H. 1996. Ranges V: An analysis system for biological location data. Institute of Terrestrial Ecology, Furzbrook Research Station, UK.

McShea, W.J. 1989. Reproductive synchrony and home range size in a territorial mocrotine. Oikos 56: $182-186$

Murakami, O., Kirana, V.L.T., Priyono J. and Tristiani, H. 1992. Tikus sawah. Final Report IndonesiaJapan Joint Program of Food Crop Protection Project (ATA 162). Directorate of Food Crop Protection. Bogor, Indonesia. 
Ostfeld, R.D. 1986. Territoriality and matting system of California voles. Journals of Animal Ecology, 55:691-706

Rahmini dan Sudarmaji. 1998. Penelitian Variasi Pakan Tikus Sawah pada Berbagai Stadia Pertumbuhan Padi, Seminar Nasional Biologi $X V$, pp: $1525-1528$

Rochman dan Sukarna, D. 1991. Pengendalian Hama Tikus. Dalam: Soenarjo E., D.S. Damardjati dan M. Syam. Eds., Padi, Buku 3, Badan Penelitian dan Pengembangan Pertanian, Bogor, pp: 751 - 767

Singleton, G.R. 2001. Rodent Impacts on Rice Production in Asia. Consultancy Report, International Rice Research Institute, Los Banos, Philippines.
Singleton, G.R. and Petch, D.A. 1994. A review of biology and management of rodent pest in Southeast Asia. ACIAR Technical repots No. 30 Australian Center for International Agricultural research, Canberra.

Smith, R.L. 1990. Ecology and field biology. $4^{\text {th }}$ ed. Harper Collins Pub. Inc. New York.

Sudarmaji. 1994. Hama Tikus dan Cara Pengendalianannya. On the job-training farmers from Tanzania held at Sukamandi, Indonesia.

Sukarna, D., Partoatmodjo, S., Wirjosuhardjo, S. and Boeadi. 1980. Problem and management of samll mammals in Indonesia with special reference to rats. Biotrop Special Pub. No 12. 